$\begin{aligned} & \text { Brain power } \\ & \text { France trials } \\ & \text { electrode treatment } \\ & \text { for obsessive disorder } \\ & p 677\end{aligned}$
m

\title{
Homeland security plan sparks fears for fight against bioterror
}

\section{Geoff Brumfiel, Washington}

President George W. Bush's proposal for a new Department of Homeland Security unveiled on 6 June - includes the reorganization of large portions of the US government's research portfolio. And scientific leaders are already fretting that the plan has the potential to disrupt important research in medicine, agriculture and nuclear weapons.

The proposed department would absorb scientific programmes worth about $\$ 3.5$ billion annually from the National Institutes of Health (NIH), the Department of Energy and other agencies to support its home defence mission. According to White House documents, the transfers would include $\$ 1.75$ billion that is currently set to be spent by the NIH next year on civilian biodefence, as well as the entire \$1.2-billion budget of the Lawrence Livermore National Laboratory (LLNL) in California, one of the United States' nuclear-weapons laboratories.

\section{Mission statement}

"I think there's a tremendous advantage to be gained by having an organization with a primary mission of homeland security, and that goes for science as well," says John Marburger, President Bush's science adviser.

Leaders of the programmes to be transferred, including Anthony Fauci, director of the National Institute for Allergies and Infectious Diseases (NIAID), which currently manages most of the NIH's biodefence funding, and Bruce Tarter, director of the LLNL, say they were not consulted about the proposed transfers. And scientific societies and other observers have questioned the usefulness and feasibility of the transfers. Congress is expected to probe the reform plan carefully and pass legislation to implement it, possibly after extensive modification, by the autumn.

The new department's research directorate would absorb the NIH's yearly biodefence budget of $\$ 1.75$ billion, but officials in the Bush administration suggest that the new department will send at least some of the money straight back to the NIH for disbursement to researchers. "There's been some talk about contracting or leasing functions

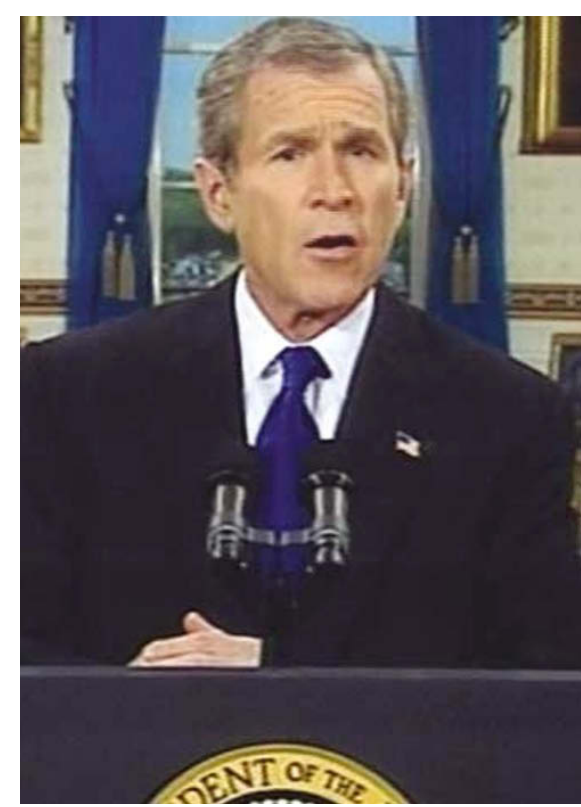

Unwieldy task: President Bush plans to bring US science to bear in the fight against terrorism.

from the NIH and not transferring them completely," says Tommy Thompson, the Health and Human Services Secretary.

But such arrangements are notoriously difficult to sustain between US government agencies. "From an operational point of view, we believe this plan is fraught with dangers," says Janet Shoemaker, head of public affairs at the American Society of Microbiology. She believes that separating biodefence research from the NIH's work on infectious diseases could weaken both programmes.

If biodefence researchers report to a new department that is less orientated towards science than the NIH, the quality of their research will suffer, critics suggest. They also question the wisdom of separating the study of diseases manipulated by humans from those that occur naturally.

The plan to transfer responsibility for LLNL may be opposed by scientists and congressmen who want the laboratory to concentrate on its nuclear-weapons work. "You can't expect a national lab to turn on a dime," says Chris Paine of the Natural
Resources Defense Council, an environmental group that monitors the laboratory. Only 18 months ago, the laboratory was placed under the control of the Department of Energy's new National Nuclear Security Administration in a bid to simplify and clarify responsibility for its management in the wake of the Wen Ho Lee spying scandal.

\section{Security concern}

"The idea is to have a national-laboratorytype enterprise whose highest priority is homeland security," Marburger explains. LLNL would receive funding for research and development related to homeland security, he adds, and the money could be spent on research either within the laboratory or outside it.

"It's a very good idea for the Department of Homeland Security to have a lead laboratory that it can turn to," says former LLNL director Michael May.

"There is already a substantial capability at Livermore," agrees John Holdren, director of the Science, Technology and Public Policy Program at Harvard University. Holdren adds that a new mission for the lab would cause few problems, provided that nuclearweapons research is allowed to continue.

The plan also calls for the transfer into the new department of the Department of Agriculture's Animal and Plant Health Inspection Service. Tony Mazzaschi, vicepresident for health research at the Association of American Medical Colleges, says that the cash-strapped service might benefit, but that it is hard to see how its main task inspecting farms and animal-research facilities - will fit into the home security mission.

And despite Bush's pledge to implement the 6 June plan in full, most details remain unresolved, and will only take firm shape as Congress moves to craft its enabling legislation. "It is one of those situations where sweeping decisions are made and the details worked out later," says Marburger. While this is happening, researchers in the affected areas will look on with some apprehension. "Our initial reaction to this," says Shoemaker, "is one of great anxiety."

Additional reporting by Erika Check and Virginia Gewin. 